\title{
The Impact of Covid-19 on Marine Ecotourism in Tegal City
}

\author{
Siswo Harsono* \\ English Department, Faculty of Humanities, Diponegoro University, Semarang-Indonesia
}

\begin{abstract}
This research investigates the impact of Covid-19 on marine ecotourism in Tegal City. As is known Covid 19 has been established by WHO as a global pandemic. Thus, the pandemic has penetrated various parts of the world, including Indonesia. In response to the prevention of the pandemic, in the city of Tegal, Central Java, Indonesia, a lockdown was carried out. With the lockdown, Tegal City Government closed local tourism spots, including marine ecotourism in Tegal city, including Alam Indah Beach, Muarareja Indah Beach, Batam Sari Beach and Kodok Beach. This research was conducted online in connection with the existence of lockdown regulations and work from home policies. The findings obtained indicate that Covid 19 has a significant effect on marine ecotourism in the city of Tegal. Lockdowns in these places paralyze the local tourism industry's economy.
\end{abstract}

Keywords: Covid 19, lockdown, marine ecotourism, new normal

\section{Introduction}

Coronavirus is the Coronaviridae family in the order of Nidovirales. Corona refers to the nail surface of a virus that resembles a crown so it is called a coronavirus. Initially, the virus appeared in a seafood market in Hunan, Wuhan, China, which also traded bats, snakes, raccoons, ferrets, and other animals. The virus then spread rapidly to 109 countries. It has been suggested that zoonotic sources suspect that bats are the main reservoir of the coronavirus [1]. Coronavirus officially named "COVID-19" is now spreading rapidly in China, and also in other countries [2].

Pandemics with symptoms of fever and severe acute respiratory distress COVID-19 in China were declared a global pandemic by the World Health Organization (WHO) on March 11, 2020 [3]. The pandemic affected the world of tourism. The bed and breakfast $(\mathrm{B} \& \mathrm{~B})$ tourism industry is undergoing a phase of recovery and must improve its health strategy, which is very significant for the tourism industry both in China and in other countries. There have been several studies conducted to examine the impact of COVID-19

* Corresponding author: siswoharsono@live.undip.ac.id 
on tourism in China, and this paper is one of the first studies to examine the impact of COVID-19 on tourist satisfaction with bed and breakfasts in China [4].

\section{Theory and methods}

The theory referred to in this paper includes the theory of marine ecotourism, marine tourism and beach tourism. This research applies online library research methods, online interviews and online discussions. This method is applied in connection with local lockdown conditions in the field, and work from home policies in the face of the Covid-19 outbreak.

\subsection{Theoretical definitions}

Ecotourism is a tourism activity that explicitly involves the observation and / or extraction of other living things in nature that are related to some form of environmental education, have a low impact on the environment, are sustainable and have an effect on local conservation. Marine ecotourism refers to natural tourism activities in the coastal and marine environment, such as hunting, camping and fishing for fresh fish [5].

The relationship between marine and coastal tourism occurs because both depend on the sea and the environment. Marine tourism activities generally occur at sea such as cruises and sailing. The beach tourism activities generally occur in coastal environments such as swimming, sunbathing, beach walks and resorts [6].

\subsection{Methods}

This research uses online library research methods, online interviews, and discussions. (1) Online library study is applied to collect marine ecotourism data in Tegal City. (2) (2) Online interviews were conducted with key informants and local tourism entrepreneurs to explore information. (3) Online discussions are held to find out the impact of Covid-19 on marine ecotourism in Tegal City [7].

\section{Findings and discussion}

Tegal City is famous for its marine ecotourism objects such as Alam Indah Beach, Muarareja Indah Beach, Pulo Kodok Beach, Pulo Komodo Beach and Batamsari Beach.

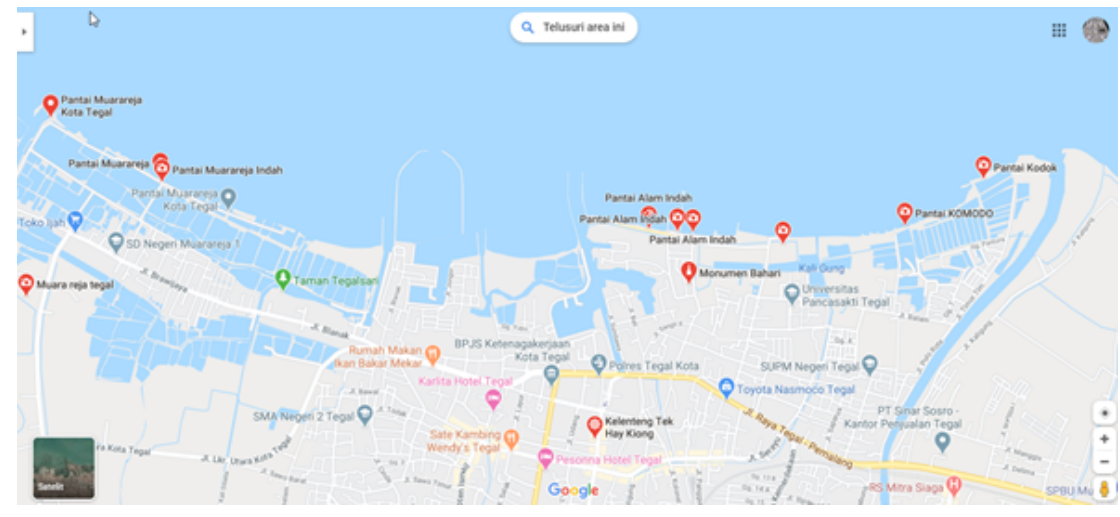

Fig. 1. Marine ecotourism map (Source: Google) 


\subsection{Local lockdown in Tegal City}

Submission of the status of large-scale social restrictions (PSBB) in Tegal City finally approved by Minister of Health Terawan Agus Putranto, which took effect on April 23, 2020 until May 23, 2020. Previously, Tegal City had made a scene by implementing local lockdowns by installing concrete in the entrance and exit access city to ward off the Corona virus. Thus as many as 49 access roads in Tegal City were closed the same as when the isolation of the territory was imposed.

The local government of Tegal Municipality, Central Java Province, announced a local lockdown on the impact of the spread of corona virus disease or covid-19. They will close their territory for four months from 30 March to 30 July 2020 after a resident is tested positive for corona virus. Then closure was also carried out at a number of public facilities. Among them are Wisanggeni Sports Hall, South Tegal Sports Hall, South Tegal Field, the tourist attraction area of Alam Indah Beach (PAI), Batamsari Beach, Pulo Kodok Beach, and Muarareja Beach.

According to Rohiman, PAI was closed by the municipal government since March 16, 2020. The closure was carried out to prevent the spread of Covid-19 following the presence of a Tegal City citizen who was exposed to a disease caused by the corona virus. "Since it was closed, around 100 traders in PAI have lost income," he said.

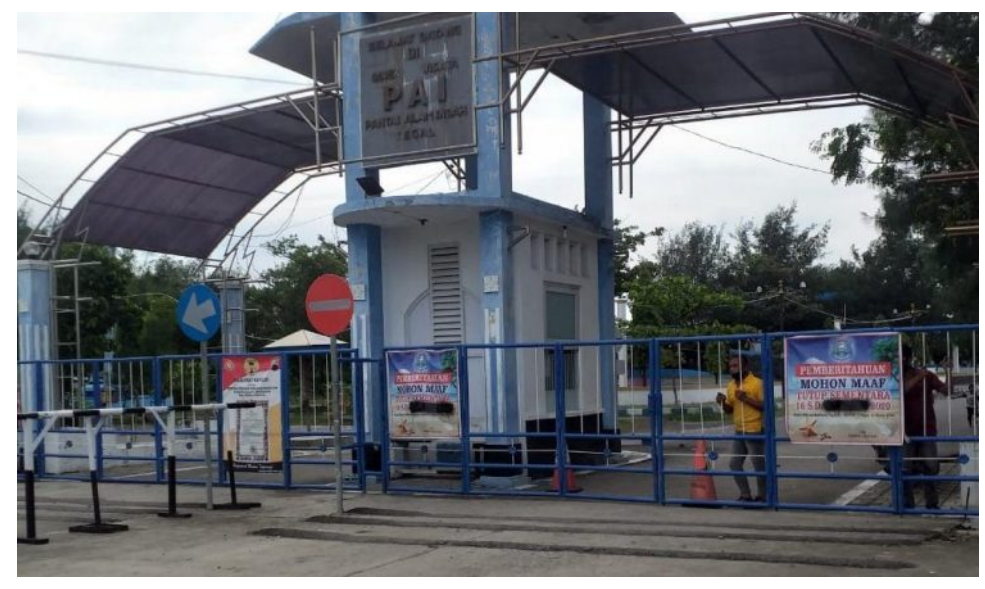

Fig. 2. The local lockdown of Alam Indah Beach (PAI) Tegal (Source: Tribun).

In the midst of the corona virus pandemic or Covid-19, traders in the Muarareja Beach has no income after the tourist attractions are advised to close by the local government. Besides Muarareja Beach, three other beaches, Alam Indah Beach (PAI), Batamsari Beach, and Pulo Kodok Beach were also closed.

A trader in Muarareja Beach, Karniasih (55) said that he and other traders have closed their businesses since mid-March. Karniasih said she and her husband to fulfill their daily needs depend on their kiosk income. According to him, income on a normal day Monday to Saturday, which is around IDR 200,000 to IDR 500,000 thousand. On weekends, daily income ranges from IDR 1,000,000 million to IDR 2,000,000.

If it is calculated, the average monthly income is IDR $85,000 \times 30$ days $=$ IDR $25,500,000$. If the local lockdown is held for three months, the loss per person reaches IDR $76,500,000$. There are 139 people doing business in Muarareja Beach, so the loss reached IDR 10,633,500,000. If it occurs in five marine ecotourism locations in Tegal City, the loss will reach IDR 53,167,500,000. 


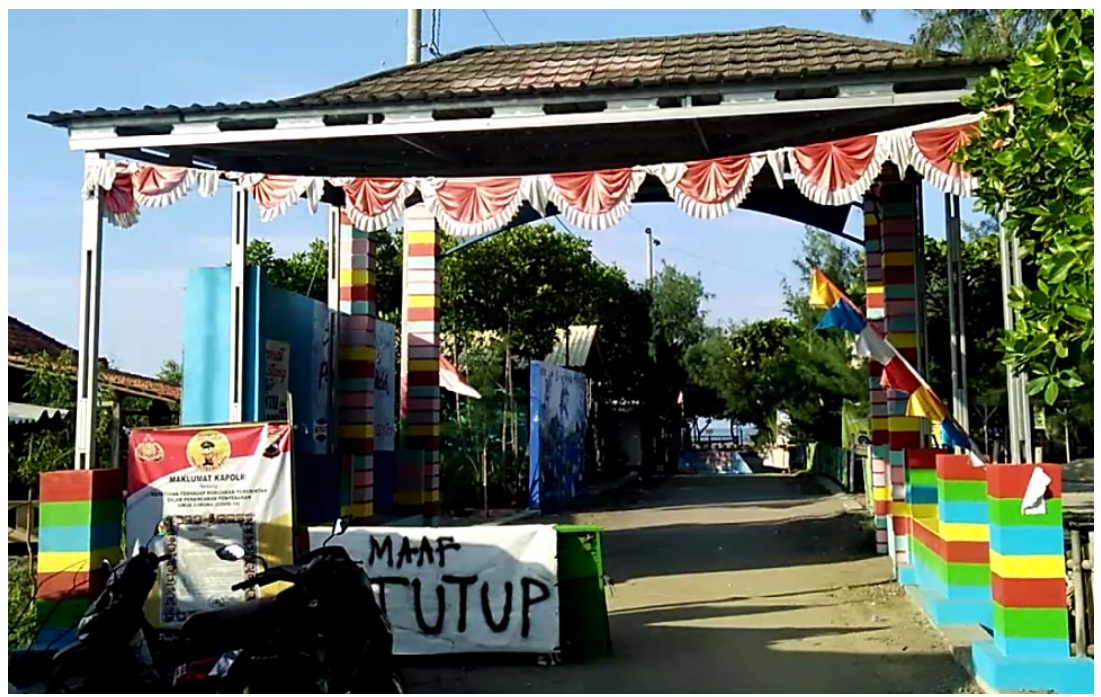

Fig. 3. Local lockdown of Muarareja beach (Source: Kabar Beritaku)

Not much different conditions also experienced by tour operators in the village of Panggung, East Tegal District. "Almost all have to be unemployed now, I myself sell fish around," said Agung one of the activists Pokdarwis on Batam Sari Beach. Previously, the man who was familiarly called Agung Brikip was a board member of Pokdarwis. The fame of the Tegal city tourism sector managed by Pokdarwis, is recognized to have resulted in high tourist arrivals. And ends in the coffers of money for business travelers and traders. But since Covid-19 became epidemic, everything has vanished.

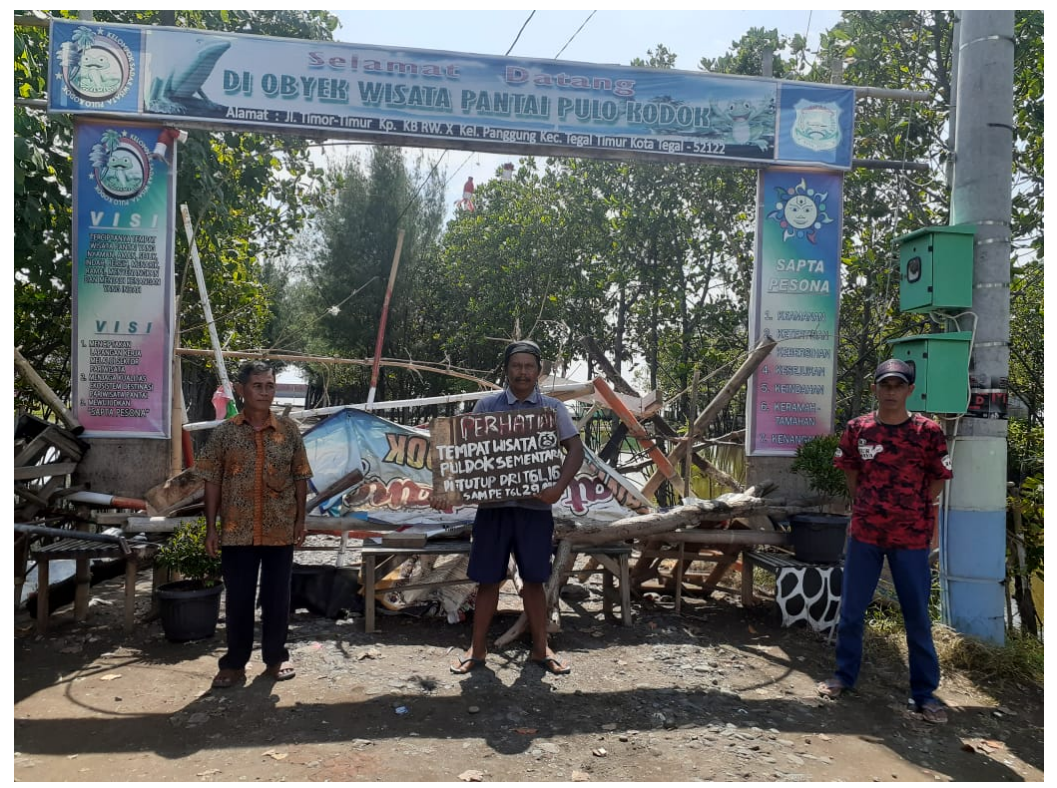

Source : Radar Tegal

Fig. 4. Tourism aware group in standing guard at Martoloyo Beach Entrance, Pulo Kodok 
Tegal is the only region in Central Java with zero positive cases of Covid-19. Thus it can be stated that the implementation of Large Scale Social Restrictions (PSBB) in Tegal City was successful. Tegal deputy mayor, Jumadi said that the implementation of local lockdown, which began on April 23, 2020 until May 23, 2020, had succeeded in disciplining its citizens with strict health protocol standards. Although at the beginning of its application there were many protests and violations, but now the community has complied and implemented the applicable rules well.

\subsection{Government aid}

Tegal City Government is ready to conduct a local lockdown on March 30 to July 30, 2020. The policy was taken to anticipate the spread of the corona virus which is known to be increasingly widespread in the area of Tegal, Central Java, Indonesia. To prepare the policy, Tegal City Government has provided a disaster budget of IDR 2 billion. The Mayor of Tegal said that as long as the policy was implemented, the City Government would provide assistance to affected poor people.

In order to meet the daily needs of Tegal City residents, Tegal Mayor, Dedy Yon Supriyono, said that the Tegal City Government has budgeted IDR 27 billion. The budget is prepared for a period of two months. He said, the funds would later be distributed to residents whose jobs depend on daily wages such as street vendors, parking attendants, online motorcycle taxi drivers. Each person will get IDR 110,000 in assistance in the form of basic commodities.

The Mayor of Tegal said that he had prepared assistance to the public during the local lockdown policy to suppress the spread of Covid-19, starting March 30 to carry out the area quarantine and the plan will continue until July 30 . He said that he had recorded residents who would receive the assistance. They included 20,000 poor people, 560 street vendors, 400 parking attendants. Then to 100 citizens who were under supervision and patients under supervision, 1000 medical workers and 50 volunteers. He said the aid distributed was IDR 110,000 of basic food, with details of 5 kilograms of rice, half a kilogram of granulated sugar, 1 pack of tea, 3 packs of instant noodles, a quarter kilogram of chicken eggs, and 1 can of sweetened condensed milk.

\subsection{New normal}

Tegal City began the new normal era from 30 May to 30 June 2020. The Mayor of Tegal said that his area was the first to start a new normal era in Indonesia. He hoped that the new normal era in Tegal City would be an example for other regions in Indonesia. He urged his citizens to orderly implement health protocols.

The decision to end the local lockdown was taken after Tegal Municipality succeeded in achieving the green zone status and ensured there were no new cases and the last patient who had contracted COVID-19 had been declared cured. As the first city in Indonesia to successfully handle COVID-19, this does not necessarily make this maritime city loosen its permanent health procedures, but continues to require people to always wear masks, wash their hands, and keep their distance while in public areas.

Tegal, the city in Java which is the earliest to do a lockdown, is now also the earliest to implement new normal. Today there is a preparation apple as well as the application of a new normality. A number of public spaces that will be opened when the new normal is put into effect are also reviewed by the Tegal City Government. Ranging from offices, malls, tourist attractions, to places of worship. Radar Tegal observations, by riding a motorcycle, the Mayor of Tegal together with the group visited a number of tourist attractions such as Alam Indah Beach, Batam Sari Beach, and Pulo Kodok Beach. 


\section{Conclusion}

The Covid 19 outbreak had a significant impact on marine ecotourism in Tegal City. The impact was mainly experienced by both tourism businesses and traders in Alam Indah Beach, Muarareja Indah Beach, Batam Sari Beach, Pulo Komodo Beach, and Pulo Kodok Beach. With the implementation of local lockdown, they automatically lose their livelihood. The total number of potensial lost is IDR 53,167,500,000. For their daily lives they received assistance from the Tegal City Government in the amount of IDR 110,000 in the form of nine staples. The total number if local government aid is IDR 27,000,000,000. This amount is only half of their earning potential. They hope that the new normal situation will revive the tourism industry economy in Tegal City.

\section{References}

1. Shereen, Muhammad Adnan, Suliman Khan, Abeer Kazmi, Nadia Bashir, and Rabeea Siddique. COVID-19 infection: Origin, transmission, and characteristics of human coronaviruses, Journal of Advanced Research 24, 91-98 (2020)

2. Ayenigbara, Israel Oluwasegun. COVID-19: An International Public Health Concern, Central Asian Journal of Global Health 9(1), 1-11 (2020)

3. Jin, Yuefei and Other. Virology, Epidemiology, Pathogenesis, and Control of Covid19, Viruses 12(372), 1-17 (2020)

4. Hong, Yan and Others. The Impact of COVID-19 on Tourist Satisfaction with B\&B in Zhejiang, China: An Importance-Performance Analysis, International Journal of Environmental Research and Public Health, 17(10), 1-19 (2020)

5. Andrew F. Johnson, Claire Gonzales, Amanda Townsel, Andrés M. CisnerosMontemayor. Marine ecotourism in the Gulf of California and the Baja California Peninsula: Research trends and information gaps, Scientia Marina 83(2), 177-185 (2019)

6. Dimas Tegar R and R.O. Saut Gurning. Development of Marine and Coastal Tourism Based on Blue Economy, International Journal of Marine Engineering Innovation and Research, 2(2), 128-132 (2018)

7. A.S. Sulitiyawati, Pengembangan Ekowisata Berbasis Kerakyatan di Banjar Nyuh Kuning, Desa Mas, Ubud, Ecotrophic JoE S. 6(2), 128-132 (2015) 